\title{
A case of late Onset Systemic Lupus Erythematosus with severe myalgia
}

\author{
Mahmoud HF \\ Geriatrics\& Gerontology department, Faculty of Medicine, Ain Shams University, Cairo, Egypt.
}

\begin{abstract}
Late onset systemic lupus erythematosus (SLE) after 50 -year-old is rare. We report a case of $\mathrm{A} 60$ year-old woman referred to our hospital because of severe myalgia and mild arthralgia together with pancytopenia without other typical symptoms of systemic lupus erythematosus (SLE). Positive direct Coomb's test revealed that anemia had autoimmune hemolytic nature and suppression of reticulocyte production was considered a clue of a process of bone marrow suppression which have been involved in the etiology of pancytopenia. Positivity for AntidsDNA antibodies led us to the diagnosis of late-onset SLE and there was marked improvement after prednisone administration. As late-onset SLE is rare and patients tend to show the typical symptoms less frequently, close attention should be focused on latent symptoms and immunological findings.
\end{abstract}

Keywords: late-onset SLE, myalgia, pancytopenia, autoimmune disorders in elderly

\section{Background:}

Systemic lupus erythematosus (SLE) is a common disease of connective tissue that predominantly affects young women in their $20 \mathrm{~s}$. In $10-20 \%$ of patients, however, the diagnosis is made for the first time in the fifth decade of life or later, indeed, the onset of SLE beyond the age of 50 years is uncommon ${ }^{1}$.

Several investigators have reported that age at onset has a modifying effect on disease expression. In comparison with younger patients, elderly patients with SLE are reported to have a more insidious onset of disease and less common occurrence of the classic manifestations of SLE ${ }^{1}$. Thus the correct diagnosis is often not made for several years and is established only after extensive diagnostic evaluation $^{2}$. It has also been noted that certain features of SLE usually associated with severity, such as nephritis or central nervous system dysfunction, are less common in patients with older-onset $\mathrm{SLE}^{3}$.

\section{Report}

A 60- year- old woman was admitted to our hospital with severe myalgia and pancytopenia. Upon admission she complained also of mild arthralgia in her shoulders, fingers and toes with morning stiffness lasting less than half an hour with easy fatigability and tingling in both upper and lower limbs and color changes in both hands especially with exposure to cold (Raynaud's phenomenon).

Patient had oral ulcers which were red tiny and superficial on the left side of the tongue, these ulcers were painful. The patient was complaining for 1.5 months before admission. Vital signs on presentation included blood pressure110/70, pulse rate $90 \mathrm{bpm}$ with regular rhythm, body temperature 37 and sometimes rises to 38 during the period of admission and respiratory rate was 18 per minute. There was small painless firm freely mobile left submandibular lymph node with no other peripheral lymphadenopathy and no edema was noted.

Chest auscultation was clear. The cardiac examination revealed a soft pansystolic murmur on tricuspid area increased with inspiration. The abdomen examination revealed hepatomegaly and dull Troube's area but spleen was not palpable. Neurological examination was normal. There was painful limitation of raising shoulders but all joints were apparently normal with no redness, swelling or tenderness. No skin rash was evident on the face or 
extremities. Laboratory data (table1) revealed normocytic anemia ( $\mathrm{Hb} 10.4 \mathrm{~g} / \mathrm{dl})$, Leucopenia (2.9 10^3/ul) with absolute neutropenia (1.61 10^3/ul), thrombocytopenia (136 10^3/ul), reticulocytopenia (0.4). Iron profile showing high ferritin level together with low serum iron and TIBC. The ESR level was highly elevated $(127 \mathrm{~mm}$ hr) and CRP $24 \mathrm{mg} / \mathrm{L}$. The serum protein level was high normal $(8.4 \mathrm{~g} / \mathrm{dl})$. The renal function tests gave normal results and urine analysis was normal and albumin was only trace and protein creatinine ratio was elevated (0.84). Liver enzymes were elevated (ALT 60 IU/ L and AST 65 IU/L). LDH was elevated (340 IU/L).

Table 1: Laboratory data on admission

\begin{tabular}{|c|c|}
\hline Hematology & Blood chemistry \\
\hline RBC $\quad 3.93 \quad 10 \wedge 6 / u l$ & BUN 16 mg/dl \\
\hline Hb $\quad 10.4 \mathrm{~g} / \mathrm{dl}$ & Creatinine $0.8 \mathrm{mg} / \mathrm{dl}$ \\
\hline $32 \%$ & $\mathrm{Na} \quad 133 \mathrm{mmol} / \mathrm{L}$ \\
\hline MCV $\quad 81.4$ fl & $4.2 \mathrm{mmol} / \mathrm{L}$ \\
\hline МCH $26.5 \mathrm{pg}$ & $\mathrm{Mg} \quad 1.7 \mathrm{mg} / \mathrm{dl}$ \\
\hline MCHC $32.5 \mathrm{~g} / \mathrm{dl}$ & Ca. total $8.4 \mathrm{mg} / \mathrm{dl}$ \\
\hline WBCs $2.910^{\wedge} 3 / \mathrm{ul}$ & Po4 $3.5 \mathrm{mg} / \mathrm{dl}$ \\
\hline Neutro. $1.6110^{\wedge} 3 / \mathrm{ul}$ & Uric acid $5.1 \mathrm{mg} / \mathrm{dl}$ \\
\hline Lymph. $1.0910^{\wedge} 3 / \mathrm{ul}$ & Total prots. $8.4 \mathrm{~g} / \mathrm{dl}$ \\
\hline Mono. $0.12 \quad 10^{\wedge} 3 / \mathrm{ul}$ & Albumin $3.2 \mathrm{~g} / \mathrm{dl}$ \\
\hline Eosino. $0.0510^{\wedge} 3 / \mathrm{ul}$ & T.bilirubin $0.6 \mathrm{mg} / \mathrm{dl}$ \\
\hline PIt. $\quad 13610^{\wedge} 3 / \mathrm{ul}$ & D. bilirub. $0.1 \mathrm{mg} / \mathrm{dl}$ \\
\hline Reticulo. $0.4 \%$ & AST $\quad 65 \mathrm{IU} / \mathrm{L}$ \\
\hline ESR $127 \mathrm{~mm} / \mathrm{hr}$ & $60 \mathrm{IU} / \mathrm{L}$ \\
\hline Hemostatic data & $128 \mathrm{mg} / \mathrm{dl}$ \\
\hline PT $13.6 \mathrm{sec}$ & LDH 340 IU/L \\
\hline INR 1.06 & $\begin{array}{ll}\text { CK-total } & 32 \mathrm{IU} / \mathrm{L} \\
\text { CK-MB } & 11 \mathrm{U} / \mathrm{L}\end{array}$ \\
\hline Serological test & Ferritin $532 \mathrm{ng} / \mathrm{ml}(\uparrow)$ \\
\hline $\begin{array}{l}\text { Serological test } \\
\text { RF +ve }\end{array}$ & $\begin{array}{l}\text { Ser. Iron } 29 \mathrm{ug} / \mathrm{dl}(\downarrow) \\
\text { TIBC } \quad 190 \mathrm{ug} / \mathrm{dl}(\downarrow)\end{array}$ \\
\hline AntiCCP (-ve) 16 & Viral markers \\
\hline $\operatorname{ANA}(\mathbf{I F}) \quad(+\mathrm{ve})$ & CMV IgG +ve $380 \mathrm{U} / \mathrm{ml}$ \\
\hline ANA(ELISA) (+ve) 5.3 & CMV IgM -ve $0.277 \mathrm{col}$ \\
\hline Anti-ds DNA(+ve) $1 / 80$ & $\mathrm{EBV}(\mathrm{VCA}) \mathrm{IgG}+\mathrm{ve} 3.65 \mathrm{IU}$ \\
\hline C3-complement $79.4(\downarrow)$ & \\
\hline $\begin{array}{l}\text { C4-complement } 15.2(\downarrow) \\
\text { Lupus anticoagulant } 28.3(\mathrm{~N})\end{array}$ & $\begin{array}{l}\mathrm{EBV}(\mathrm{VCA}) \mathrm{IgM}-\mathrm{ve} \quad 0.62 \mathrm{IU} \\
/ \mathrm{ml}\end{array}$ \\
\hline Coombs test direct + ve & $\mathrm{HIV} \mathrm{Ag} / \mathrm{Ab} \quad-\mathrm{ve}$ \\
\hline Coombs test indirect -ve & HBs Ag -ve \\
\hline CRP $24 \quad \mathrm{mg} / \mathrm{L}$ & $\mathrm{HCV} \mathrm{Ab} \quad-\mathrm{ve}$ \\
\hline $\begin{array}{l}\text { Urine analysis } \\
\text { Pus 6-8 } \\
\text { RBCs } 0-2 \\
\text { Alb. trace }\end{array}$ & $\begin{array}{l}\text { Prot./Creat. Ratio } \\
0.84(\uparrow)\end{array}$ \\
\hline
\end{tabular}

Immunological tests showed that the patient was positive for antinuclear antibodies (ANA) by ELISA (5.3) and also positive by indirect immunoflurescence of speckeld and rim pattern. Rheumatoid factor was positive and AntiCCP was negative. Anti-DNA antibodies were positive with a titer of 1/80. C3 and C4 were consumed. Lupus anticoagulant was normal. Serological tests showed evidence of resolving CMV infection.

Bone marrow aspirate revealed mild hypocellular particles however the trails were normocellular with Myeloid / Erythroid ratio was 4:1, suggesting the presence of mild erythroid hypoplasia. The myelopoeisis shows mild maturation arrest at myelocytes state with increased eosinophils. No increase in the number of blast cells was observed ( $<1 \%$ of ANCs), hemophagocytosis was not detected in the bone marrow.

Pan CT revealed bilateral subcentimetric upper and lower cervical and submandibular lymphadenopathy. Subcentimetric mediastinal (prevascular, retrocaval) and bilateral axillary lymphadenopathy and multiple small para aortic, common, external, internal iliac, inguinal lymphadenopathy. Liver is enlarged in size about $17.5 \mathrm{~cm}$ with normal density of liver parenchyma. Renal biobsy revealed Focal sclerosing lupus nephritis class $ш(\mathrm{C}), \mathrm{NIH}$ Activity Index 3/24, NIH Chronicity Index 4/12.

The presence of Anti-ds DNA antibodies, specific antibodies for SLE, and normal bone marrow findings suggested that autoimmunity might be involved in the peripheral pancytopenia. Positivity of the direct coombs test suggested autoimmune hemolytic anemia as a complication.

The patient was diagnosed as having SLE on the basis of 2015 ACR/SLICC (American College of Rheumatology /Systemic Lupus International Collaborating Clinics) Revised Criteria for Diagnosis of Systemic Lupus Erythematosus, in view of the presence of oral ulcers, arthralgia, proteinuria, hemolytic anemia, WBCs $<4000$, positive FANA of rim pattern, positive anti-dsDNA and consumed $\mathrm{C} 3$ and $\mathrm{C} 4$. The patient was treated with pulse steroid for 3 days followed by oral prednisone $30 \mathrm{mg} / \mathrm{day}$, after 10 days oral prednisone there was evident improvement of anemia, leucopenia and thrombocytopenia even AST and ALT were normalized (table 2) and myalgia and patient function markedly improved.

Table (2): Laboratory data after 10 days oral

\begin{tabular}{|c|c|}
\hline CBC & Blood chemistry \\
\hline $\begin{array}{lll}\text { RBC } & 3.96 & 10 \wedge 6 / u l\end{array}$ & Creatinine $0.8 \mathrm{mg} / \mathrm{dl}$ \\
\hline Hb $\quad 11 \mathrm{~g} / \mathrm{dl}$ & Sodiun $133 \mathrm{mmol} / \mathrm{L}$ \\
\hline Ht $\quad 33.1 \%$ & Potassium $5.3 \mathrm{mmol} / \mathrm{L}$ \\
\hline MCV 83.6 fl & AST $\quad 42 \quad \mathrm{IU} / \mathrm{L}$ \\
\hline МСH 27.7 pg & $30 \quad \mathrm{IU} / \mathrm{L}$ \\
\hline МСНC $33.1 \mathrm{~g} / \mathrm{dl}$ & Albumin $\quad 3.6$ \\
\hline WBCs $4.9 \quad 10^{\wedge} 3 / u l$ & \\
\hline Neutro. $4.0410^{\wedge} 3 / u l$ & \\
\hline Lymph. $0.6510^{\wedge} /$ ul & \\
\hline Mono. $0.1910^{\wedge} 3 / \mathrm{ul}$ & \\
\hline Eosino. $0.0110^{\wedge} 3 / \mathrm{ul}$ & \\
\hline Plt. $\quad 18510^{\wedge} 3 / \mathrm{ul}$ & \\
\hline
\end{tabular}




\section{Discussion:}

Late onset systemic lupus erythematosus after 80years old is exceptional ${ }^{4}$. A few cases have been reported. It differs from systemic lupus with early onset in term of clinical presentation, pattern of organ involvement and prognosis. Also, the female predominance is less observed (sex ratio $6-10 / 1 \mathrm{Vs} 3.2-4.4 / 1)^{5}$.

The sex hormones modifications may play a part in determining the expression of the disease ${ }^{6}$.

The interval between the symptom onset and the diagnosis of SLE is longer in the late onset SLE with a delay of over 5 years ${ }^{4}$. The clinical presentation of late onset SLE patients varies in different series. Commonly reported clinical features include fever, weight loss, musculoskeletal complaints and pleuropericarditis ${ }^{7}$.

Arthralgia and findings resembling polymyalgia rheumatica are initial manifestations of late onset SLE ${ }^{9}$. Consistent with these features, the present patient had arthralgia in her shoulders, fingers and toes and lacked typical symptoms such as skin manifestations. Cytopenias are found more commonly in late onset$\mathrm{SLE}^{10}$, and were present as a complication in this patient. Immunological abnormalities observed in this patient, are less frequent in other reported elderly persons ${ }^{8}$.Although it has been reported that anti-ds DNA antibodies and anti-Sm antibodies are present less frequently in late onset-SLE patients ${ }^{11}$, some authors have demonstrated a higher prevalence of anti-Sm antibodies in both younger and elderly patients ${ }^{12}$. Antids DNA antibodies were detected in the present case and this led us to the diagnosis of SLE. Involvement of major organ, especially the kidney is exceptional in late onset $\mathrm{SLE}^{13}$. In this patient, the diagnosis of lupus nephritis was based on proteinuria which was confirmed with renal biobsy.

Our patient fulfilled the ACR (The American College of Rheumatology) criteria 2015.

\section{Conclusion:}

Diagnosis of SLE in elderly individuals is difficult because of the lack of typical physical and laboratory features that are usually present in younger patients. Therefore, careful attention needs to be paid to latent symptoms and immunological laboratory findings.

\section{References}

1. Baker S B, Rovira J R, Campion G V, Mills J A. Late onset systemic lupuserythematosus. AmJ Med 1979; 66: 727-32.

2. Foad B S I, Sheon R P, Kirsner A B. Systemic lupus erythematosus in the elderly. Arch Intern Med 1972; 130: 743-6.

3. Hochberg M C, Boyd R E, Ahearn J H. Systemic lupus erythematosus: a review of clinicolaboratory features and immunogenetic markers in 150 patients with emphasis on demographicsubsets. Mediine(Baltimore) 1985;64:285-95.

4. Takeda N, Teramoto S, Ihn H, Arao T, Matsuse T, Toba K. et al. [A case of very late onset overlap syndrome of systemic sclerosis and systemic lupus erythematosus]. Nippon Ronen Igakkai Zasshi 2000; 37 (1): 74- 9.

5. Boddaert J, Huong DL, Amoura Z, Wechsler B, Godeau P, Piette JC. Late-onset systemic lupus erythematosus: a personal series of 47 patients and pooled analysis of 714 cases in the literature. Medicine (Baltimore) 2004; 83 (6): 348- 59

6. Ho CT, Mok CC, Lau CS, Wong RW. Late onset systemic lupus erythematosus in southern Chinese. Ann Rheum Dis 1998; 57 (7): 437- 40.

7. Font J, Pallares L, Cervera R, Lopez-Soto A, Navarro M,Bosch X, et al. Systemic lupus erythematosus in the elderly: 67 clinical and immunological characteristics . Ann Rheum Dis 1991; 50 (10): 702 5.

8. Shaikh SKJ and Wang F, Late-Onset Systemic Lupus Erythematosus: Clinical and Immunological Characteristics. Med J Malaysia 1995; 50: 25-31.

9. Hutton CW and Maddison PJ. Systemic lupus erythematosus presenting as polymyalgia rheumatica in the elderly.Annals of the Rheumatic Diseases 1986; 45:641-644

10. Knockaert DC, Vanderschueren, and Blockmans D. Fever of unknown origin in adults: 40 years on. J Intern Med 2003; 253:263275 .

11. Rovensky $J$ and Tuchynova A. Systemic lupus erythematosus in the elderly. Autoimmunity Reviews 2008; 7:235-239.

12. Font J, Pallares $\mathrm{L}$, Cervera $\mathrm{R}$ et al. Systemic lupus erythematosus in the elderly: clinical and immunological characteristics. Annals of the rheumatic Diseases 1991; 50: 702-705.

13. Cervera R, Khamashta MA, Font J, Sebastiani GD, Gil A, Lavilla P et al; European Working Party on Systemic Lupus Erythematosus. Morbidity and mortality in systemic lupus erythematosus during a 10-year period: a comparison of early and late manifestations in a cohort of 1,000 patients. Medicine (Baltimore) 2003; 82 (5): 299 308

Corresponding Author: Hend F Mahmoud: $\underline{\text { hm.hend@yahoo.com }}$ 